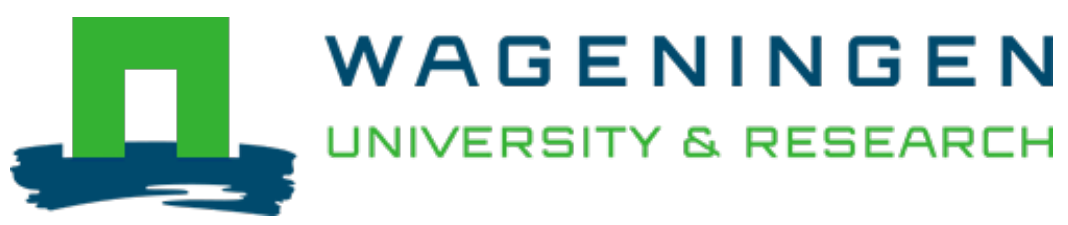

\title{
Indigenous fermented foods
}

Food microbiology: fundamentals and frontiers, 3rd edition

Nout, M.J.R.; Sarkar, P.K.; Beuchat, L.R.

This publication is made publicly available in the institutional repository of Wageningen University and Research, under the terms of article $25 \mathrm{fa}$ of the Dutch Copyright Act, also known as the Amendment Taverne. This has been done with explicit consent by the author.

Article 25 fa states that the author of a short scientific work funded either wholly or partially by Dutch public funds is entitled to make that work publicly available for no consideration following a reasonable period of time after the work was first published, provided that clear reference is made to the source of the first publication of the work.

This publication is distributed under The Association of Universities in the Netherlands (VSNU) 'Article $25 \mathrm{fa}$ implementation' project. In this project research outputs of researchers employed by Dutch Universities that comply with the legal requirements of Article $25 \mathrm{fa}$ of the Dutch Copyright Act are distributed online and free of cost or other barriers in institutional repositories. Research outputs are distributed six months after their first online publication in the original published version and with proper attribution to the source of the original publication.

You are permitted to download and use the publication for personal purposes. All rights remain with the author(s) and / or copyright owner(s) of this work. Any use of the publication or parts of it other than authorised under article $25 \mathrm{fa}$ of the Dutch Copyright act is prohibited. Wageningen University \& Research and the author(s) of this publication shall not be held responsible or liable for any damages resulting from your (re)use of this publication.

For questions regarding the public availability of this publication please contact openscience.library@wur.nl 


\author{
M. J. Robert Nout \\ Prabir K. Sarkar \\ Larry R. Beuchat
}

\title{
Indigenous Fermented Foods
}

\begin{abstract}
A food is considered fermented when one or more of its constituents have been acted upon by selected microorganisms or their enzymes to produce a significantly altered final product desirable for human consumption. Most fermentations are caused by molds, yeasts, or bacteria, either singularly or in combination. Indigenous or traditional fermented foods have been prepared and consumed for hundreds of years and are strongly linked to cultures and traditions of millions of people around the world, especially in rural communities. The origins of most fermentation technologies have been lost in the mists of history. Some products and practices no doubt fell by the wayside; those that remain today have survived the test of time. Fermented food products are important components of the diet as staples, adjuncts to staples, condiments, and beverages.

This oldest form of food biotechnology originated as a necessity for enhancing the keeping quality of diverse plant and animal food materials through organic acid, alcoholic, and alkaline fermentations. Fermentation, a relatively efficient low-energy preservation process, also improves digestibility, flavor, appearance, nutrient
\end{abstract}

contents, and other quality attributes and reduces antinutritional components of the substrates and cooking time. Many fermented foods are now receiving global attention for their health-promoting or disease-preventing or -curing effects. Whereas a considerable number of food fermentation processes have been scaled up for commercial purposes, most types of fermented foods are still produced on a home scale. Such products often contain mixed genera and populations of microorganisms because of the lack of controlled processing facilities. In view of larger-scale industrialized food fermentation, microbial ecology and metabolic activities of functional microorganisms must be investigated. Present-day developments in molecular methods enable accurate characterization of strains and development of tailor-made fermented food products.

A variety of fermented foods can be found widespread over the world. Following the sequence in Table 38.1, some of them will be described in this chapter, mainly to illustrate the complexity of biochemical, nutritional, and sensorial changes that result from an array of microbial activities in a range of raw materials.

M. J. Robert Nout, Dept. of Agrotechnology and Food Sciences, Wageningen University, Bomenweg 2, 6703HD Wageningen, The Netherlands. Prabir K. Sarkar, Dept. of Botany, University of North Bengal, Siliguri 734013, India. Larry R. Beuchat, Center for Food Safety, University of Georgia, 1109 Experiment St., Griffin, GA 30223-1797. 
Table 38.1 Some important indigenous fermented foods

\begin{tabular}{|c|c|c|c|c|c|}
\hline Product(s) & $\begin{array}{l}\text { Country(ies) } \\
\text { and/or area(s) }\end{array}$ & Substrate(s) & $\begin{array}{l}\text { Functional } \\
\text { microflora }^{a}\end{array}$ & $\begin{array}{c}\text { Type(s) of } \\
\text { fermentation }^{b}\end{array}$ & Description and usage \\
\hline \multicolumn{6}{|c|}{ Cereal and starch crop products } \\
\hline Ang-kak & $\begin{array}{l}\text { China, Southeast } \\
\text { Asia }\end{array}$ & Rice & Molds & SSF, TS & $\begin{array}{l}\text { Dry purple-red powder; } \\
\text { colorant }\end{array}$ \\
\hline Banku & Egypt & Maize or cassava & Yeasts, LAB & SSF, $\mathrm{N}$ & Dumpling; staple \\
\hline Ben-saalga & Burkina Faso & Pearl millet & Bacteria, LAB & SmF, N & $\begin{array}{l}\text { Sour, thin gruel; breakfast } \\
\text { staple and infant food }\end{array}$ \\
\hline Bhatura & India, Pakistan & Wheat & LAB, yeasts & SSF, TS & $\begin{array}{l}\text { Deep-fried, flat, leavened } \\
\text { bread; snack }\end{array}$ \\
\hline Bouza & Egypt & Wheat & Yeasts, LAB & SmF, TS & $\begin{array}{l}\text { Pale yellow, thick, sour } \\
\text { alcoholic drink }\end{array}$ \\
\hline $\begin{array}{l}\text { Breads (leavened } \\
\text { yeast and sour- } \\
\text { dough breads) }\end{array}$ & Worldwide & Wheat and/or rye & $\begin{array}{l}\text { Bakers' yeast } \\
\text { or yeast-LAB } \\
\text { mixed cultures }\end{array}$ & SSF & Baked leavened dough; staple \\
\hline Busaa & Kenya, Uganda & $\begin{array}{l}\text { Maize, finger } \\
\text { millet }\end{array}$ & Yeasts, LAB & $\mathrm{SmF}, \mathrm{N}$ & Sour alcoholic drink \\
\hline Chicha & South America & Maize & $\begin{array}{l}\text { Molds, yeasts, LAB, } \\
\text { AAB }\end{array}$ & SmF, N & $\begin{array}{l}\text { Clear, yellowish, effervescent, } \\
\text { sour alcoholic drink }\end{array}$ \\
\hline Deguè & Burkina Faso & Pearl millet & Bacteria, molds & SSF, $\mathrm{N}$ & $\begin{array}{l}\text { Balls diluted with milk or } \\
\text { water to make porridge }\end{array}$ \\
\hline Gari & $\begin{array}{l}\text { Nigeria, West } \\
\text { Africa }\end{array}$ & Cassava & LAB, yeasts & SSF, N & $\begin{array}{c}\text { Granulate; precooked instant } \\
\text { porridge; breakfast staple }\end{array}$ \\
\hline Injera & Ethiopia, Sudan & $\begin{array}{l}\text { Teff (or corn or } \\
\text { sorghum) }\end{array}$ & LAB, yeasts & SSF, N & $\begin{array}{l}\text { Sour, soft, steam-baked, flat } \\
\text { pancake; staple }\end{array}$ \\
\hline Jalebi & India & Wheat & LAB, yeasts & SSF, N & Pretzel-like syrupy confection \\
\hline Jnard & $\begin{array}{l}\text { India, Nepal, } \\
\text { Bhutan }\end{array}$ & Finger millet & $\begin{array}{l}\text { Molds, yeasts, } \\
\text { LAB }\end{array}$ & SSF, TS & Sweet-sour alcoholic drink \\
\hline Kenkey & Ghana & Maize & LAB, yeasts & SSF, N & Sour dumpling; cooked; staple \\
\hline Lafun & $\begin{array}{l}\text { Nigeria, West } \\
\text { Africa }\end{array}$ & Cassava & $\mathrm{LAB}$ & SmF, N & $\begin{array}{l}\text { White flour made into a stiff } \\
\text { porridge; staple }\end{array}$ \\
\hline Lao-chao & China, Indonesia & Rice & Molds, yeasts & SmF, TS & $\begin{array}{l}\text { Sweet-sour, juicy, alcoholic } \\
\text { snack }\end{array}$ \\
\hline Mahewu & South Africa & Maize & LAB & SmF, N & Sour, nonalcoholic drink \\
\hline Mawè & Benin, Togo & Maize & LAB, yeasts & SSF, N & $\begin{array}{l}\text { Sourdough made into porridge } \\
\text { or gruel; staple }\end{array}$ \\
\hline Merissa & Sudan & Sorghum & LAB, yeasts & SSF-SmF, N & Thick, sour alcoholic drink \\
\hline Minchin & China, Thailand & Wheat (or rice) & Molds & SSF, N & Thin strips or noodles; staple \\
\hline Munkoyo & Zambia, Zaire & Maize & LAB, yeasts & SmF, N & Sweet-sour alcoholic drink \\
\hline Naan & $\begin{array}{l}\text { Afghanistan, Iran, } \\
\text { Pakistan, India }\end{array}$ & Wheat & Yeasts, LAB & SSF, $\mathrm{N}$ & Flat, baked bread; staple \\
\hline Ogi & $\begin{array}{l}\text { Nigeria, West } \\
\text { Africa }\end{array}$ & $\begin{array}{l}\text { Maize or sorghum } \\
\text { or millet }\end{array}$ & $\begin{array}{c}\text { Molds, yeasts, } \\
\text { AAB, LAB }\end{array}$ & SmF, N & Sour gruel; staple \\
\hline Pito & Nigeria, Ghana & Sorghum or maize & $\begin{array}{l}\text { Molds, LAB, } \\
\text { yeasts }\end{array}$ & SmF, TS & Sweet-sour alcoholic drink \\
\hline Poi & Hawaii & Taro corm & LAB, yeasts & SSF, N & $\begin{array}{l}\text { Sour porridge; staple or } \\
\text { condiment }\end{array}$ \\
\hline Poto-poto & Congo & Maize & LAB, yeasts & SSF, N & $\begin{array}{l}\text { Sourdough balls made into } \\
\text { porridge or gruel; staple }\end{array}$ \\
\hline Pozol & Mexico & Nixtamal $^{c}$ & $\begin{array}{l}\text { Molds, yeasts, } \\
\text { LAB, other } \\
\text { bacteria }\end{array}$ & SSF, $\mathrm{N}$ & $\begin{array}{l}\text { Balls diluted with water to } \\
\text { make sour, nonalcoholic } \\
\text { porridge }\end{array}$ \\
\hline Puto & Philippines & Rice & LAB, yeasts & SSF, $\mathrm{N}$ & Spongy, steamed cake; snack \\
\hline Ruou nep than & Vietnam & Rice & Molds, yeasts & SSF-SmF, TS & Alcoholic drink \\
\hline
\end{tabular}


Table 38.1 (Continued)

\begin{tabular}{|c|c|c|c|c|c|}
\hline Product(s) & $\begin{array}{l}\text { Country(ies) } \\
\text { and/or area(s) }\end{array}$ & Substrate(s) & $\begin{array}{l}\text { Functional } \\
\text { microflora }^{a}\end{array}$ & $\begin{array}{c}\text { Type(s) of } \\
\text { fermentation }^{b}\end{array}$ & Description and usage \\
\hline Saké & Japan & Rice & $\begin{array}{l}\text { Molds, yeasts, } \\
\text { bacteria, LAB }\end{array}$ & SmF, TS & Alcoholic drink \\
\hline Tapé & Indonesia & Cassava or rice & Molds, yeasts & SSF, TS & Sweet-sour alcoholic snack \\
\hline Tapuy & Philippines & Rice & Yeasts, LAB & SSF, TS & Sour-sweet alcoholic drink \\
\hline Yakju and Takju & Korea & Rice & $\begin{array}{l}\text { Molds, yeasts, } \\
\text { LAB, other } \\
\text { bacteria }\end{array}$ & SSF-SmF, TS & Alcoholic drink \\
\hline \multicolumn{6}{|l|}{ Legume products } \\
\hline Daddawa & $\begin{array}{l}\text { West Africa, } \\
\text { Nigeria }\end{array}$ & $\begin{array}{l}\text { African locust } \\
\text { bean }\end{array}$ & Bacteria & SSF, $\mathrm{N}$ & $\begin{array}{l}\text { Flavoring agent; soup and stew } \\
\text { ingredient }\end{array}$ \\
\hline Inyu & $\begin{array}{l}\text { Taiwan, China, } \\
\text { Hong Kong }\end{array}$ & Black soybeans & $\begin{array}{l}\text { Molds, LAB, } \\
\text { yeasts }\end{array}$ & SmF, N & Syrup; flavor enhancer \\
\hline Kecap asin & Indonesia & Soybeans & $\begin{array}{l}\text { Molds, LAB, } \\
\text { yeasts }\end{array}$ & SSF-SmF, TS & $\begin{array}{l}\text { Thin, transparent, light brown } \\
\text { salty liquid; condiment }\end{array}$ \\
\hline Kecap manis & Indonesia & $\begin{array}{l}\text { Soybeans, palm } \\
\text { sugar, herbs }\end{array}$ & $\begin{array}{l}\text { Molds, LAB, } \\
\text { yeasts }\end{array}$ & SSF-SmF, TS & $\begin{array}{l}\text { Thick, dark brown syrup; } \\
\text { sweet condiment }\end{array}$ \\
\hline Kinema & India, Nepal & Soybeans & Bacteria & SSF, $\mathrm{N}$ & $\begin{array}{l}\text { Paste made into thick curry; } \\
\text { side dish }\end{array}$ \\
\hline Meitauza & China, Taiwan & $\begin{array}{l}\text { Soybean press } \\
\text { cake }\end{array}$ & Molds & SSF, $\mathrm{N}$ & $\begin{array}{l}\text { Cake, fried or cooked; side } \\
\text { dish }\end{array}$ \\
\hline Meju & Korea & Black soybeans & $\begin{array}{l}\text { Molds, LAB, } \\
\text { yeasts }\end{array}$ & SSF-SmF, N & Syrup; seasoning agent \\
\hline Natto & Japan & Soybeans & Bacteria & SSF, PS & Mucilaginous snack \\
\hline Oncom & Indonesia & $\begin{array}{l}\text { Peanut press } \\
\text { cake }\end{array}$ & Molds & SSF, TS & $\begin{array}{l}\text { Cake, deep fried or roasted; } \\
\text { side dish or soup ingredient }\end{array}$ \\
\hline Papad & $\begin{array}{l}\text { India, Pakistan, } \\
\text { Bangladesh }\end{array}$ & Black gram & Yeasts & SSF, $\mathrm{N}$ & $\begin{array}{l}\text { Deep-fried or roasted snack or } \\
\text { condiment }\end{array}$ \\
\hline Sufu & China, Taiwan & Soybean curd & Molds & SSF, N & Paste; condiment \\
\hline Tempeh & Indonesia & Soybeans & Molds, bacteria & SSF, TS & $\begin{array}{l}\text { White, mold-penetrated and } \\
\text { covered cake, stewed or } \\
\text { deep fried; side dish, snack, } \\
\text { or soup ingredient }\end{array}$ \\
\hline Wadi & $\begin{array}{l}\text { India, Pakistan, } \\
\text { Bangladesh }\end{array}$ & Black gram & LAB, yeasts & SSF, $\mathrm{N}$ & Balls or cones; condiment \\
\hline \multicolumn{6}{|c|}{ Cereal-legume mixture products } \\
\hline Dhokla & India & Rice, Bengal gram & LAB, yeasts & SSF, N & Steamed, soft cake; snack \\
\hline Idli & India, Sri Lanka & Rice, black gram & LAB, yeasts & SSF, N & Steamed, spongy cake; snack \\
\hline Miso & Japan & Soybeans, rice & $\begin{array}{l}\text { Molds, yeasts, } \\
\text { LAB }\end{array}$ & SSF, TS & $\begin{array}{l}\text { Paste; soup base or seasoning } \\
\text { agent }\end{array}$ \\
\hline Soy sauces & $\begin{array}{l}\text { East and South- } \\
\text { east Asia }\end{array}$ & Soybeans, wheat & $\begin{array}{l}\text { Molds, LAB, } \\
\text { yeasts }\end{array}$ & SSF-SmF, TS & $\begin{array}{l}\text { Brown, salty liquid; seasoning } \\
\text { agent }\end{array}$ \\
\hline Taoco & Indonesia & Soybeans, cereals & $\begin{array}{l}\text { Molds, LAB, } \\
\text { yeasts }\end{array}$ & SSF-SmF, TS & Yellow paste; seasoning agent \\
\hline \multicolumn{6}{|l|}{ Vegetable products } \\
\hline Gundruk & India, Nepal & Mustard leaves & $\mathrm{LAB}$ & SSF, N & $\begin{array}{l}\text { Shreds; soup ingredient or } \\
\text { pickle }\end{array}$ \\
\hline $\begin{array}{l}\text { Soibum, Mesu, } \\
\text { Naw-Mai- } \\
\text { Dong }\end{array}$ & $\begin{array}{l}\text { India, Nepal, } \\
\text { Thailand }\end{array}$ & $\begin{array}{l}\text { Young bamboo } \\
\text { shoot }\end{array}$ & LAB, yeasts & SSF, $\mathrm{N}$ & $\begin{array}{l}\text { Cubes; consumed as a pickle } \\
\text { or made into curry }\end{array}$ \\
\hline
\end{tabular}


Table 38.1 Some important indigenous fermented foods (Continued)

\begin{tabular}{|c|c|c|c|c|c|}
\hline Product(s) & $\begin{array}{l}\text { Country(ies) } \\
\text { and/or area(s) }\end{array}$ & Substrate(s) & $\begin{array}{l}\text { Functional } \\
\text { microflora }^{a}\end{array}$ & $\begin{array}{l}\text { Type(s) of } \\
\text { fermentation }^{b}\end{array}$ & Description and usage \\
\hline Kanji & $\begin{array}{l}\text { India, Pakistan, } \\
\text { Israel }\end{array}$ & Carrot or beet & Yeasts & SmF, $\mathrm{N}$ & $\begin{array}{l}\text { Deep purple, sour, alcoholic } \\
\text { drink }\end{array}$ \\
\hline Kimchi & Korea & $\begin{array}{l}\text { Cabbage (or rad- } \\
\text { ish taproot), } \\
\text { garlic }\end{array}$ & $\mathrm{LAB}$ & SSF, $\mathrm{N}$ or TS & $\begin{array}{l}\text { Sour, carbonated vegetable; } \\
\text { staple }\end{array}$ \\
\hline Sauerkraut & $\begin{array}{l}\text { Europe, Russia, } \\
\text { United States }\end{array}$ & White cabbage & $\mathrm{LAB}$ & $\begin{array}{l}\text { SSF-SmF, } \mathrm{N} \text { or } \\
\text { PS }\end{array}$ & $\begin{array}{l}\text { Sour shreds; consumed raw } \\
\text { or cooked with meat or } \\
\text { sausages }\end{array}$ \\
\hline Sinki & India, Nepal & Radish taproot & $\mathrm{LAB}$ & SSF, N & $\begin{array}{l}\text { Sour shreds; pickle or soup } \\
\text { ingredient }\end{array}$ \\
\hline \multicolumn{6}{|l|}{ Dairy products } \\
\hline $\begin{array}{l}\text { Gorgonzola, Blue } \\
\text { Stilton, Roque- } \\
\text { fort cheese }\end{array}$ & $\begin{array}{l}\text { Italy, United King- } \\
\text { dom, France }\end{array}$ & $\begin{array}{l}\text { Cow's or sheep's } \\
\text { milk }\end{array}$ & LAB, molds & SSF, TS or PS & $\begin{array}{l}\text { Blue-veined cheese; strong- } \\
\text { flavored side dish or cooking } \\
\text { ingredient }\end{array}$ \\
\hline Camembert cheese & France & Cow’s milk & LAB, molds & SSF, TS or PS & $\begin{array}{l}\text { Mold surface-ripened cheese; } \\
\text { soft-texture side dish with } \\
\text { gradually developing strong } \\
\text { flavor }\end{array}$ \\
\hline Dahi & $\begin{array}{l}\text { India, Pakistan, } \\
\text { Bangladesh, } \\
\text { Sri Lanka }\end{array}$ & $\begin{array}{l}\text { Cow's or buffalo's } \\
\text { milk }\end{array}$ & $\mathrm{LAB}$ & SmF, N or PS & Thick gel; dessert \\
\hline Gouda cheese & The Netherlands & Cow's milk & LAB & SSF, TS or PS & $\begin{array}{l}\text { Small-eyed or blind cheese; } \\
\text { multipurpose protein food }\end{array}$ \\
\hline Kefir & $\begin{array}{l}\text { Scandinavia, } \\
\text { Russia }\end{array}$ & $\begin{array}{l}\text { Goat's, sheep's, } \\
\text { or cow's milk }\end{array}$ & Yeasts, LAB & SmF, TS & $\begin{array}{l}\text { Effervescent, sour, mild } \\
\text { alcoholic drink }\end{array}$ \\
\hline Koumiss & Russia & Mare’s milk & LAB, yeasts & SmF, N & $\begin{array}{l}\text { Effervescent, cloudy, sour, } \\
\text { alcoholic drink }\end{array}$ \\
\hline Lassi & India & $\begin{array}{l}\text { Cow's or buffalo's } \\
\text { milk }\end{array}$ & $\mathrm{LAB}$ & SmF, $\mathrm{N}$ & Sour drink \\
\hline Yogurt & $\begin{array}{l}\text { Europe, world- } \\
\text { wide }\end{array}$ & Cow's milk & $\mathrm{LAB}$ & SmF, TS or PS & $\begin{array}{l}\text { Viscous or thick gel; dessert or } \\
\text { side dish }\end{array}$ \\
\hline \multicolumn{6}{|l|}{ Fish products } \\
\hline Bagoong & Philippines & $\begin{array}{l}\text { Fish or shrimp or } \\
\text { oyster }\end{array}$ & Bacteria & SSF, N & Brown paste; condiment \\
\hline Izushi & Japan & $\begin{array}{l}\text { Fish, rice, veg- } \\
\text { etable }\end{array}$ & $\mathrm{LAB}$ & SSF, N & Pickle \\
\hline Katsuobushi & Japan & $\begin{array}{l}\text { Bonito or skipjack } \\
\text { tuna }\end{array}$ & Molds & SSF, N & Strips, dried; seasoning agent \\
\hline Som-fak & Thailand & $\begin{array}{l}\text { Fish fillet, rice, } \\
\text { garlic }\end{array}$ & $\mathrm{LAB}$ & SSF, N & $\begin{array}{l}\text { Served raw or cooked; main } \\
\text { course or snack }\end{array}$ \\
\hline \multicolumn{6}{|l|}{ Meat products } \\
\hline $\begin{array}{l}\text { Country-cured } \\
\text { ham }\end{array}$ & $\begin{array}{l}\text { Europe, United } \\
\quad \text { States }\end{array}$ & Pork & $\begin{array}{l}\text { Bacteria, LAB, } \\
\text { molds }\end{array}$ & SSF, N & $\begin{array}{l}\text { Cured meat; ham slices con- } \\
\text { sumed raw or cooked }\end{array}$ \\
\hline Nem & Vietnam & Pork, garlic & Bacteria, LAB & SSF, $\mathrm{N}$ or $\mathrm{TS}$ & Meat cubes, fried; side dish \\
\hline Nham & Thailand & Pork, cooked rice & LAB & SSF, N & $\begin{array}{l}\text { Sour slices, deep fried, crispy; } \\
\text { snack }\end{array}$ \\
\hline Salami & $\begin{array}{l}\text { Europe, United } \\
\text { States }\end{array}$ & Pork and beef & LAB & SSF, $\mathrm{N}$ or PS & Sausage \\
\hline
\end{tabular}


Table 38.1 (Continued)

\begin{tabular}{|c|c|c|c|c|c|}
\hline Product(s) & $\begin{array}{l}\text { Country(ies) } \\
\text { and/or area(s) }\end{array}$ & Substrate(s) & $\begin{array}{l}\text { Functional } \\
\text { microflora }^{a}\end{array}$ & $\begin{array}{c}\text { Type(s) of } \\
\text { fermentation }^{b}\end{array}$ & Description and usage \\
\hline \multicolumn{6}{|c|}{ Miscellaneous products } \\
\hline Balao balao & Philippines & Rice, shrimp & LAB & SSF, N & Main dish or sauce \\
\hline Basi & Philippines & Sugarcane juice & Yeasts, LAB & SmF, TS & $\begin{array}{l}\text { Sweet-sour, effervescent, } \\
\text { cloudy, alcoholic drink }\end{array}$ \\
\hline Bongkrek & Indonesia & $\begin{array}{l}\text { Coconut press } \\
\text { cake }\end{array}$ & Molds & SSF, TS & $\begin{array}{l}\text { Bars, roasted or fried; snack or } \\
\text { soup ingredient }\end{array}$ \\
\hline Kishk & $\begin{array}{l}\text { Egypt, Syria, } \\
\text { Lebanon, } \\
\text { Jordan, Iraq, } \\
\text { North Africa }\end{array}$ & Wheat, milk & $\begin{array}{l}\text { LAB, yeasts, } \\
\text { other bacteria }\end{array}$ & SSF, N & $\begin{array}{l}\text { Brownish, sour, dried balls; } \\
\text { snack or soup ingredient }\end{array}$ \\
\hline Kombucha & $\begin{array}{c}\text { Japan, Indonesia, } \\
\text { China, Russia }\end{array}$ & Tea liquor, sugar & $\mathrm{AAB}$, yeasts & SmF, TS & Sour, mildly alcoholic drink \\
\hline $\begin{array}{l}\text { Miang, or } \\
\text { Leppet-So }\end{array}$ & $\begin{array}{l}\text { Myanmar, Thai- } \\
\text { land }\end{array}$ & Tea leaves & LAB & SSF, N & Sour-bitter tasting soft snack \\
\hline $\begin{array}{l}\text { Tarhana, or } \\
\text { Trahana }\end{array}$ & Turkey, Greece & $\begin{array}{l}\text { Tomatoes, wheat } \\
\text { flour }\end{array}$ & Yeasts & SSF, $\mathrm{N}$ or PS & $\begin{array}{l}\text { Tomato dough, dehydrated } \\
\text { granulate; soup ingredient }\end{array}$ \\
\hline Palm wines & $\begin{array}{l}\text { All tropical } \\
\text { palm-growing } \\
\text { countries }\end{array}$ & $\begin{array}{l}\text { Sap of coconut, } \\
\text { date, palmyra, } \\
\text { oil, nipa, ra- } \\
\text { phia, or kithul } \\
\text { palm }\end{array}$ & $\begin{array}{l}\text { Yeasts, LAB, } \\
\text { bacteria, AAB }\end{array}$ & SmF, N & Sweet-sour alcoholic drink \\
\hline Ugba, or Ogiri & $\begin{array}{l}\text { Nigeria, West } \\
\text { and Central } \\
\text { Africa }\end{array}$ & $\begin{array}{l}\text { African oil bean } \\
\text { or castor oil } \\
\text { beans or melon } \\
\text { or sesame seeds }\end{array}$ & Bacteria & SSF, N & $\begin{array}{l}\text { Dark brown balls; salad ingre- } \\
\text { dient or flavoring agent in } \\
\text { soups, stews, and sauces }\end{array}$ \\
\hline
\end{tabular}

a $\mathrm{AAB}$, acetic acid bacteria; $\mathrm{LAB}$, lactic acid bacteria.

${ }^{b}$ SSF, solid-state fermentation; SmF, submerged fermentation; SSF-SmF, solid-state fermentation followed by submerged fermentation; N, natural and/or backslopped fermentation; TS, traditional undefined starter; PS, pure culture starter.

${ }^{c}$ Corn grains cooked in alkaline water.

\section{CEREAL AND STARCH CROP PRODUCTS}

\section{Bakery Products}

Bread, in various forms, has been a staple in the diets of many population groups for many centuries. The history of bread traces back to about 3,000 в.с. The development of cereal foods has proceeded through several stages, from roasted grain to gruels to flat breads and finally to leavened bread loaves. Early Egyptians developed the use of fermentation for breads and constructed baking ovens. We will focus here on leavened breads owing their sensorial properties, at least in part, to fermentative activities of microorganisms.

In principle, bread is made from dough that is fermented and baked. The essential ingredients are wheat or rye flour, salt, water, and a leavening agent (26). Usually some fat, sugar, milk solids, and bread-improving emulsifiers are added, but these are not essential. The function of water (50 to $60 \%$ of flour weight) is to hydrate the starch and gluten (extensible and elastic proteins in wheat), enabling the mixing and kneading of a viscoelastic dough that retains the carbon dioxide gas formed during fermentation. The most commonly used leavening agent is bakers' yeast, Saccharomyces cerevisiae (27), which is commercially available as dehydrated granules (instant dry yeast), fresh yeast cake, or yeast cream (a suspension). Dry yeast must first be reactivated in a flourwater suspension for about $20 \mathrm{~min}$. Yeast cream and cake have the advantage that no activation is required, but they are prone to spoilage by lactic acid bacteria (LAB) and thus have limited shelf lives. Based on flour weight, about 1 to $6 \%$ yeast dry matter is required. The function of salt (1 to $2 \%$ ) is to moderate the fermentation rate in order to obtain a steady production of gas that can be adequately retained in the dough. After fermentation for several hours at 25 to $30^{\circ} \mathrm{C}$, doughs are remixed to obtain a homogenous distribution of gas cells. The dough is portioned to the required weight or size and is 
molded and put into baking pans. After another period of fermentation, the dough has at least doubled its volume and is baked in a hot-air or steam oven for 20 to $40 \mathrm{~min}$ at temperatures ranging from 180 to $230^{\circ} \mathrm{C}$.

Sourdough bread is slightly acidic because of the leavening agent, sourdough. In contrast to the pure-culture bakers' yeast, sourdough comprises a stable, mixed microflora containing $10^{7}$ to $10^{9} \mathrm{LAB} \mathrm{CFU} / \mathrm{g}$, predominantly Lactobacillus sanfransiscensis and occasionally Lactobacillus pontis, Lactobacillus panis, Lactobacillus frumenti, or Lactobacillus reuteri, and $10^{5}$ to $10^{7}$ yeast CFU (predominantly Candida milleri)/g, obtained by repeated propagation of sourdough fermentations by reinoculation. Long-term propagation of a sourdough during the last seven decades has been documented (16), and anecdotal reports exist of sourdoughs maintained over several centuries. Commercial sourdough starters have been developed and are available as dehydrated granules and (semi)dried preferments. Sourdoughs are required for rye breads to achieve bakeability, and they are widely used in rye and wheat breads because of the high sensory quality they impart to these breads. Sourdough contributes to the characteristic flavor (61), improves texture, and delays staling and microbial spoilage of bread (60).

Naan (nan) is made by mixing white wheat flour with sugar, salt, backslop (called khamira), and water. The hand-kneaded dough is left in an earthen jar to ferment for 12 to $24 \mathrm{~h}$. After maturity, the leavened dough is made into balls, placed on a smooth surface sprinkled with flour, and flattened by a wooden rolling pin. Smoothly flattened round dough is transferred onto a circular pad of cotton cloth and is slapped onto the inner wall of the clay-clad brick oven, called the tandoor, where it sticks for baking at 120 to $150^{\circ} \mathrm{C}$ until the dough is puffed off and light brown. The bread is speared with a skewer and removed from the oven wall to be served hot, usually along with meat or chicken preparations. From a new dough ( $\mathrm{pH} 5.9$ ) for making naan, $10^{5} \mathrm{CFU}$ of yeasts/g and $10^{2} \mathrm{CFU}$ of $\mathrm{LAB} / \mathrm{g}$ can be obtained compared with respective counts of $10^{8}$ and $10^{9} \mathrm{CFU} / \mathrm{g}$ from ripe, fermented dough ( $\mathrm{pH} 4.8$ ) (5). S. cerevisiae is the predominant yeast. Presently, bakers' yeast and dahi are added to shorten the fermentation period.

\section{Kenkey}

Kenkey is a dense, sour-tasting, cooked mass, served as thick slices at breakfast combined with tea, sardines, or other foods. Cleaned whole corn (maize, Zea mays) kernels are soaked in water for 2 days; during this period, the kernels soften (43), which is essential during the next operation, i.e., coarse wet milling. The resulting wet grits are kneaded into a stiff dough, which is covered and left to ferment at ambient temperature $\left(25\right.$ to $\left.30^{\circ} \mathrm{C}\right)$ for 2 to 4 days. Dominant microorganisms are obligate heterofermentative lactobacilli, e.g., Lactobacillus fermentum, and yeasts, mainly Candida krusei and S. cerevisiae. When fermented according to local preference for odor and acidity (28), the dough is divided into two equal portions, and one portion is cooked, with the addition of some water, while being kneaded continuously with a cooking stick into an elastic gelatinized paste called aflata. The aflata is then mixed through the remaining uncooked dough. The resulting mass is molded by hand into units of 200 to $400 \mathrm{~g}$ and wrapped in banana leaves (Fanti kenkey) or corn sheaths (Ga kenkey). The packages are cooked by immersion in boiling water for a few hours. The function of the aflata is twofold: it acts as an adhesive, keeping the mixture in shape, and it carries the water needed for the swelling (gelatinization) of the uncooked, gritty dough. During the fermentation, the level of available lysine (and thus protein quality) and nutrient bioavailability increase, and flavor compounds (2,3-butanediol, butanoic acid, lactic acid, 3-methylbutanoic acid, octanoic acid, 2-phenylethanol, and propanoic acid) are formed (28).

\section{Mawè}

Mawè is an intermediate product used for the preparation of, e.g., ablo, a steam-cooked corn bread, and porridge, e.g., aklui (23). To prepare mawè, cleaned, dry, whole corn kernels are milled into grits, partly reground to obtain a fine grind, mixed with water, kneaded into a dough, covered, and allowed to ferment naturally during 2 to 4 days at ambient temperature $\left(30^{\circ} \mathrm{C}\right)$. The $\mathrm{pH}$ decreases to 3.7 to 3.8 , and an attractive freshly sour flavor is formed due mainly to heterofermentative lactobacilli (Lb. fermentum and Lactobacillus cellobiosus) and C. krusei.

\section{Ogi}

To prepare ogi, kernels of corn are soaked in warm water for 1 to 3 days, after which they are wet milled and sieved with water through a screen to remove fiber, hulls, and much of the germ. The filtrate is fermented to yield a sour, white, starchy sediment. Fermentation is by lactobacilli ( $L b$. fermentum, Lb. cellobiosus, Lactobacillus brevis, and Lactobacillus plantarum) originating from the environment, although other bacteria (Enterobacter sakazakii and Corynebacterium spp.) and yeasts (C. krusei, Candida kefyr, and Rhodotorula spp.) are also involved (42). Ogi may be diluted in water to 8 to $10 \%$ solids and boiled into a pap or cooked and turned into a stiff gel (eko) before eating. 
Ogi is a major breakfast cereal for adults and a traditional food for weaning babies. As a result of the preparation method, significant $(40 \%)$ losses of protein occur but the digestibility of the remaining protein is improved by $20 \%$ (42). In Nigeria, industrialization of ogi manufacture has taken place (54), enabling better control of quality and hygiene. Based on upgraded village technology, the final product is packaged and distributed as a long-shelf-life dehydrated powder, obtained by rotary drying or spray drying of the fermented wet cake. The nutritional value of ogi can be improved by enrichment with soybeans to obtain a $15 \%$ protein content $(54)$.

\section{Pozol}

Pozol, which dates back to the Aztec period, is made from nixtamal, which consists of corn kernels that have been boiled in lime water containing about $10 \%$ calcium hydroxide. This treatment, which probably evolved from the use of naturally occurring alkaline water of volcanic origin, facilitates the swelling of the corn and removal of pericarps (decortication). The resulting cooked endosperms are washed, drained, and milled to obtain masa, a coarse paste which is molded into balls (51), wrapped in banana leaves, and left to ferment for 1 to 2 weeks at ambient temperature $\left(22\right.$ to $\left.27^{\circ} \mathrm{C}\right)$. During the process, the $\mathrm{pH}$ increases to about 7.5 after nixtamilization and then gradually decreases to 3.8 to 4.0 after 1 week due to fermentative acidification, dominated by LAB. Streptococcus spp. account for 25 to $50 \%$ of the microflora, and $L b$. plantarum and Lb. fermentum, together with Leuconostoc and Weissella species, are the other dominant microorganisms (4). Yeasts, including Candida spp. and Trichosporon cutaneum, are encountered in combination with the LAB (51). When left to ferment for longer periods, yeasts and molds (Geotrichum candidum and Rhizopus spp.) develop on the surface (51), imparting a musty flavor. In addition to the development of desired flavor, fermentation also contributes to the digestibility and increased riboflavin, niacin, and tryptophan contents of the product.

\section{Ang-Kak}

Red kojic rice (ankak, or anka) is made by solid-state fermentation of cooked rice with the ascomycetous molds Monascus spp. Rice is washed, steamed for about $1 \mathrm{~h}$, cooled to $36^{\circ} \mathrm{C}$, inoculated with starter, heaped to ferment until the temperature rises to $42^{\circ} \mathrm{C}$, and then spread and shelved. It is used in the fermentation industry for coloring red rice wine and foods such as sufu, fish sauce, and red soybean curd. The azaphilone pigments produced by Monascus ruber, Monascus pilosus, and Monascus purpureus include the orange rubropunctatin and monascorubrin, purple rubropunctamin and monascorubramin, and yellow ankaflavin and monascin (59), which are heat stable over a wide range of $\mathrm{pHs}$ and thus of interest as biocolorants in foods. Several other secondary metabolites are produced, including xanthomonasins, monascumic acid, monascusones, monacolins, and $\gamma$-aminobutyric acid. The pleasant flavor of ang-kak is derived from alcohols, aldehydes, ketones, esters, and terpenoid compounds.

Of recent interest are the potential health-promoting effects of ang-kak, such as cholesterol-lowering ability due to mevonolin (monacolin K), hypotensive effects due to $\gamma$-aminobutyric acid, and anti-inflammatory effects (3). The optimum cultural conditions for the production of pigments by a Monascus sp. isolated from the solid koji of Kaoliang liquor are reported to be $\mathrm{pH} 6.0$ for a 3-day incubation at $32^{\circ} \mathrm{C}$. Among the carbon sources tested, starch, maltose, and galactose are suitable for pigment production; a starch content of $3.5 \%$ (5\% rice powder) and a sodium or potassium nitrate content of $0.5 \%$ gave maximum yield of pigment in laboratory media. Zinc may act as a growth inhibitor of Monascus purpureus and concomitantly as a stimulant for glucose uptake and the synthesis of secondary metabolites such as pigments.

\section{Ragi}

The Indonesian word ragi refers to a starter or inoculum, and the name following ragi indicates the intended use of the starter, e.g., ragi-tempe, ragi-tapé, ragi-peuyeum, and ragi-tapai. Similar starters are Indian bakhar, Nepalese murcha, Thai loog-pang, Vietnamese men, Philippine bubod, Malaysian jui-paing, Chinese chu, Japanese tane koji, and Korean nuruk. To prepare ragi, rice flour is mixed with a variety of herbs, spices, and water to make dough which is inoculated by dusting with powdered ragi from a previous batch, flattened into cakes (about $3 \mathrm{~cm}$ in diameter and $1 \mathrm{~cm}$ thick), placed on a bamboo tray, covered with leaves or a cloth, incubated for 2 to 5 days at ambient temperature $\left(20\right.$ to $\left.30^{\circ} \mathrm{C}\right)$, air or sun dried, and preserved until needed.

A widely used type of ragi and ragi-like starters combines three groups of microorganisms, mucoraceous fungi, yeasts, and LAB (45). Ragi contains molds, namely Amylomyces rouxii and Aspergillus, Mucor, and Rhizopus spp. Amylomyces reproduces through thick-walled chlamydospores which ensure survival when the starter cakes are dried and stored prior to being used. Among the diverse yeast species in ragi, Saccharomycopsis fibuligera and Pichia anomala are the principal amylolytic and ethanol-producing yeasts, respectively. Pediococcus pentosaceus, Weissella spp., Lactobacillus curvatus, and Enterococcus faecium form the LAB component of ragi microflora (70). The microflora of ragi varies with the location and additives used. The molds and several 
yeasts convert starchy materials into fermentable sugars, which are subsequently converted into ethanol by the yeasts and organic acids by the LAB and molds.

\section{Puto}

To make puto, rice grains are soaked, ground to a semipaste consistency (called galapong), mixed with starter (called lebadura), and fermented at two different stages, during which time the volume and lactic acid content increase 3- and 20-fold, respectively. The fermented batter is poured into molds and steam cooked for 15 to $30 \mathrm{~min}$ to make puto. The predominant microorganism in the fermenting batter is always Leuconostoc mesenteroides (30), followed by Enterococcus faecalis and then $S$. cerevisiae and Pediococcus dextrinicus. The yeasts produce low levels of ethanol and, along with L. mesenteroides, leaven the batter, rendering a spongy texture to the product.

\section{Rice Beers}

Although the term "rice wine" is also in use for a ricefermented alcoholic drink, the term "rice beer" is technically correct because, like beer, rice beer is produced from grain rather than fruit and it undergoes a twostage fermentation process wherein starches in the rice are broken down into sugars which are then converted into alcohol. While most of these processes still follow indigenous technology, significant development in the manufacturing process has been made in Japan, China, and Korea; modern Japanese saké manufacture is highly sophisticated. The manufacture of rice beers can be characterized as a biotechnological process which includes steaming, inoculation with starter, mashing, and fermentation. The microorganisms involved in the fermentations of some rice beers are listed in Table 38.2. Depending on the fermentation performance, the ethanol content varies and can reach up to $15 \%$ ( $\mathrm{vol} / \mathrm{vol})(14,15)$.

\section{Injera}

To prepare injera, teff flour and water are combined with irsho, a fermented yellow fluid saved from a previous batch. The resultant thin, watery paste is generally incubated for 1 to 3 days. A portion of the fermented paste is then mixed with 3 parts water and boiled to give a product called absit, which is in turn mixed with a portion of the original fermented flour to yield a thin injera. Thick injera (aflegna) is a teff paste that has undergone only minimal fermentation ( 12 to $24 \mathrm{~h}$ ) and is characterized by a sweet flavor and a reddish color. A third type of injera (komtata) is made from overfermented paste and, consequently, has a sour taste, probably due to extensive growth of LAB (17). Although the microflora compositions responsible for fermentation of the sweeter types of injera have not been fully determined, Candida guilliermondii is apparently a primary yeast in this process. The carbon sources for fermentation originate from the grain. Initially, a rise in free sugars, mainly sucrose, takes place, followed by a decline due to microbial assimilation (72). Regardless of the method used to prepare injera,

Table 38.2 Microorganisms involved in the production of Asian rice beers

\begin{tabular}{|c|c|c|}
\hline Beer(s) & Starter & Functional microorganisms \\
\hline Brem & Ragi-tapé & $\begin{array}{l}\text { Amylomyces spp., Mucor spp., Rhizopus spp., Saccha- } \\
\text { romyces cerevisiae, Candida glabrata, Pichia anomala, } \\
\text { Issatchenkia orientalis }\end{array}$ \\
\hline Ruou nep than & Men & $\begin{array}{l}\text { Amylomyces rouxii, Rhizopus spp., Saccharomyces cerevi- } \\
\text { siae, Pichia anomala }\end{array}$ \\
\hline Saké, Mirin & Tane-koji & $\begin{array}{l}\text { Aspergillus oryzae, Saccharomyces sake, Pichia anomala, } \\
\text { Lactobacillus sakei }\end{array}$ \\
\hline $\begin{array}{l}\text { Sato, Ou, } \\
\quad \text { Nam-Khao }\end{array}$ & Loog-pang & Mucor spp., Rhizopus spp., Candida spp., Saccharomyces spp. \\
\hline Shaoshing & Chu & Aspergillus oryzae, Rhizopus spp., Saccharomyces cerevisiae \\
\hline Takju, Yakju & Nuruk & $\begin{array}{l}\text { Aspergillus spp., Mucor spp., Rhizopus spp., Saccharomyces } \\
\text { cerevisiae, Pichia anomala, Hansenula subpelliculosa, } \\
\text { Candida spp., Debaryomyces polymorphus, Lactobacillus } \\
\text { plantarum, Leuconostoc mesenteroides }\end{array}$ \\
\hline Tapai & Jui-piang & $\begin{array}{l}\text { Amylomyces rouxii, Rhizopus oryzae, Mucor spp., Saccha- } \\
\text { romycopsis fibuligera, Pichia anomala }\end{array}$ \\
\hline Tapuy & Bubod & $\begin{array}{l}\text { Rhizopus oryzae, Amylomyces rouxii, Saccharomycopsis } \\
\text { fibuligera, Rhodotorula glutinis, Debaryomyces hansenii, } \\
\text { Candida sp., Lactobacillus plantarum, Leuconostoc spp. }\end{array}$ \\
\hline
\end{tabular}


the fermented dough with batter consistency is baked on a hot, oiled clay griddle for a few minutes, resulting in a large, pancake-like bread injera.

\section{Gari}

Fermented root of the cassava plant (Manihot esculenta) is known as gari in the rain forest belt of West Africa. To prepare gari, the corky outer peel and the thick cortex are removed and the inner portion of the root is grated. The pulp is then packed into jute bags, and weights are applied to express some of the juice. After 3 to 4 days of fermentation, cassava is sieved and heated while constantly turning over a hot steel pan. This process is known as garification. The final product contains 10 to $15 \%$ moisture, 80 to $85 \%$ starch, $0.1 \%$ fat, 1 to $1.5 \%$ crude protein, and 1.5 to $2.5 \%$ crude fiber. Palm oil may be added as a colorant just before or after drying. For the production of 1 ton of gari, 4 tons of cassava roots are required. Cassava is a highly perishable crop once harvested; garification is a clever approach to achieve a safe, shelf-stable product. In Nigeria, gari production has been industrialized (55).

Fresh cassava roots of bitter varieties contain cyanogenic glycosides, viz., linamarin and lotaustralin, that decompose during the fermentation of gari with the liberation of gaseous hydrocyanic acid. The hydrolysis of cyanogenic glycosides is due mainly to endogenous linamarinase, reducing cyanide levels from $300 \mathrm{mg}$ (initial) to 10 to $20 \mathrm{mg}$ of $\mathrm{HCN} / \mathrm{kg}$ of product (55). Lb. plantarum and other LAB contribute significantly to decreasing the $\mathrm{pH}$ (74). The acid condition favors fungal growth, mainly that of Galactomyces candidum, which contributes to the characteristic aroma and flavor by its aldehydes and esters.

\section{Tapé}

Tapé ketan (rather similar to lao-chao) and tapé ketella are prepared by fermenting rice and cassava, respectively. Glutinous rice or peeled and chopped cassava root is soaked, steam cooked until soft, spread in thin layers onto bamboo trays, inoculated with powdered ragi-tapé (starter), and left to ferment under cover for 1 to 3 days at 27 to $30^{\circ} \mathrm{C}$ to produce a soft, white mass (65). The essential biochemical changes, caused by Amylomyces rouxii and Pichia burtonii, are the hydrolysis of starch into maltose and glucose and the conversion of a part of the sugars into alcohol and organic acids, thereby imparting a sweet-sour taste to the product.

\section{Poi}

To prepare poi, the corm of the taro plant (Colocasia esculenta) is cooked for several hours by baking or steaming, peeled, ground, combined with water to make a smooth, sticky paste, and stored airtight for 2 to 3 days at ambient temperature (8). Lactobacillus delbrueckii and Lactococcus lactis predominate in the early stages of fermentation, lowering the $\mathrm{pH}$ to 3.8 to 4.0 . These bacteria, along with Saccharomyces kefyr, produce a large amount of lactic acid and moderate amounts of acetic, propionic, succinic, and formic acids. Candida vini and Geotrichum candi$d u m$, which are prevalent in the later stages of fermentation, impart a pleasant fruity aroma to mature poi.

\section{LEGUME PRODUCTS}

\section{Daddawa}

Daddawa (dawadawa) preparation is still largely a family art practiced at home. Seeds of the African locust bean tree (Parkia biglobosa) are washed to remove yellow powdery pulp, leaving black beans which are then boiled in water in a covered container for 18 to $24 \mathrm{~h}$, with occasional replenishing of water to swell the seeds and soften the very tough seed coats, which are then removed by pounding and rinsing. The cotyledons are reboiled for $30 \mathrm{~min}$ to $2 \mathrm{~h}$ when a native softening agent called kuru (containing mostly potash) is added. The cotyledons are drained, heaped (10 to $15 \mathrm{~cm}$ deep) in calabash trays or dumped in a hole in the ground, and covered with locally available leaves and sackcloth. Beans are left to ferment for 2 to 4 days at 25 to $35^{\circ} \mathrm{C}$, during which time they become dark brown and covered in a sticky mucilaginous layer and develop a pungent odor. The bean mass is air dried in the sun or hot shade, where the beans darken further, and the beans are then used loose or shaped into balls or pyramids $(9,63)$.

Although daddawa is dominated and produced mainly by Bacillus subtilis, it contains several other species of Bacillus and Leuconostoc $(52,63)$. During fermentation, the temperature of $25^{\circ} \mathrm{C}$ and the $\mathrm{pH}$ of 7.0 of the beans increase to $45^{\circ} \mathrm{C}$ and $\mathrm{pH} 8.1$ at $36 \mathrm{~h}$. The content of free amino acids increases fivefold due to extensive proteolysis. Certain antinutritional factors such as oligosaccharides, phytic acid, and oxalate decrease during fermentation (52).

\section{Kinema}

Kinema resembles natto except that, although in natto intact whole soybeans are used, in kinema the beans are crushed to form grits about half the size of cotyledons. Kinema is a naturally fermented product, containing Bacillus spp., enterococci, and yeasts. However, B. subtilis is the principal bacterium in the microflora and is largely responsible for the production of kinema. Spores of $B$. subtilis, which are normally present on soybeans, survive the cooking treatment to initiate and carry out 
the fermentation. Strong proteolytic activity causes an increase in $\mathrm{pH}$ from an initial $\mathrm{pH}$ of 6.9 to a $\mathrm{pH}$ of 8.6 at the end of fermentation $(62,63)$.

\section{Meitauza}

Meitauza is prepared from okara (insoluble carbohydrate residue that is left over after the production of soy milk or tofu) which is ground, steeped, strained, and formed into round cakes 10 to $14 \mathrm{~cm}$ in diameter and 2 to $3 \mathrm{~cm}$ thick at the middle and 1 to $1.3 \mathrm{~cm}$ thick at the edges. The cakes are placed in a vessel and left to ferment with moderate aeration until, after 10 to 15 days, they are covered with white mycelium of Actinomucor elegans. The molded cakes are then sun dried. Meitauza is served either fried in vegetable oil or cooked with vegetables as a flavoring agent (56).

\section{Natto}

Natto, a popular breakfast and dinner item in Japan, is usually eaten with rice along with soy sauce and spicy mustard. It is the only food in the category of alkaline fermentations that has been industrialized (62). With the use of whole soybeans, three types of natto are prepared. Yukiwari-natto and hama-natto are koji (Aspergillus oryzae)-based products, while the more common itohiki-natto is a Bacillus-fermented product. Itohikinatto, generally referred to as natto, is popular in the eastern Kanto region (Tokyo). Natto soybeans are small (up to $5.5 \mathrm{~mm}$ in diameter) with a clear hilum, thin seed coat, and high carbohydrate content. Smaller beans are preferred, as the fermentation process reaches the center of the beans easier. To prepare natto traditionally, soybeans are washed, soaked overnight, boiled until tender (approximately $15 \mathrm{~min}$ ), drained, partially air dried for 20 min over bamboo trays, and put into shallow paper containers covered with wax paper. The containers are stacked in large wooden boxes, covered with straw mats, and left near an oven at approximately $36^{\circ} \mathrm{C}$ to ferment for 1 day. Intentional inoculation is not necessary because straw contains the fermenting microorganism, B. subtilis. However, not all strains of $B$. subtilis are suitable for making good natto (53).

Yukiwari-natto is made by mixing itohiki-natto with rice koji and salt and then aging at 25 to $30^{\circ} \mathrm{C}$ for about 2 weeks. To prepare hama-natto, washed soybeans are soaked in water for $4 \mathrm{~h}$ and steamed for $1 \mathrm{~h}$. After cooling, the beans are inoculated with koji, fermented for about $20 \mathrm{~h}$, dried to a moisture content of $12 \%$, submerged in brine, and aged for 6 to 12 months.

Natto is prized for its high nutritional value and improved digestibility, both resulting from fermentation. The nature of the free amino acid profile of natto is similar to that of kinema (44). Natto has a characteristic pungent but pleasant aroma. Sulfur-containing compounds deriving from the cooked soybeans and pyrazines formed during fermentation are the main contributors to the characteristic natto odor. The sulfur compounds include 4-ethyl-2-methylthiazole, 3,5-dimethyl-1,2,4-trithiolane, and thialdine. The pyrazines present at the highest concentrations include tetramethyl, trimethyl, and 2,5-dimethyl derivatives (57). Natto is also characterized by the presence of a sticky paste on its surface. When stirred, the paste increases in volume and becomes stickier and is held together like a spider web by gossamer-like threads. Natto mucin contains $22 \%$ fructan and $78 \%$ poly-DL-glutamic acid with a $\gamma$-peptide linkage ( $\gamma$-PGA) which has a high viscoelasticity and is spinnable due to the formation of network structures of randomly coiled $\gamma$-PGA through intermolecular $\mathrm{H}$ bondings in the presence of fructan (25). Production of $\gamma$-PGA in the natto strains of B. subtilis is regulated by the comQXPA quorum-sensing system and is genetically unstable because of the translocation of IS4Bsu1 into the comP gene at a high frequency (41). The IS4Bsu1 is widely distributed among $B$. subtilis strains in other similar soybean-fermented foods, such as kinema, Thai thua-nao, Chinese douchi, Korean chungkuk-jang, and Burmese chine pepoke (24). Natto mucin can absorb 5,000 times its weight in water, and this remarkable property has been put to use in cosmetics and wrappings of food products.

\section{Oncom}

Oncom is a by-product of peanut oil pressing, produced by soaking peanut (Arachis hypogaea) press cake for 1 day, mixing with starchy ingredients such as cassava residues, steaming for about $1 \mathrm{~h}$, cooling, and inoculating with pregrown fungal mycelium, usually Neurospora sitophila or Neurospora intermedia. The inoculated dough is molded to form brick-shaped pieces that are incubated for a few days in banana leaves at ambient temperature $\left(25\right.$ to $\left.30^{\circ} \mathrm{C}\right)(31)$. Oncom hitam (black oncom) and oncom merah (yellow-red oncom) contain different mycofloras. The merah type contains mainly Neurospora, whereas hitam is dominated by Rhizopus spp. Rhizopus sporangiospores are black due to melanoids, and carotenoids form the basis of the orange-yellow color of Neurospora.

Oncom flavor has been described as fruity and somewhat alcoholic; after frying, mincemeat or almond flavors can be detected. The enzymatic activities (lipases, proteases) provoke an increase in free fatty acids and degradation of proteins, resulting in improved protein digestibility which is relevant for consumers with digestive disorders. Recently, experiments with oncom-miso made 
from soybeans and oncom demonstrated increased antioxidative and antimutagenic activity associated with the enzymatic release of isoflavone-aglycones (37). Instead of dry, spore-based starters, starters used for oncom are propagated and maintained by mycelial growth in a kind of fed-batch solid-state fermentation kept active by the processors. Although very little controlled experimentation has been done on this fermentation, it is presumed that a method of vegetative propagation is needed because the Neurospora spores have limited viability when stored dry and have poor germination ability.

\section{Sufu}

Actinomucor elegans $(7,21)$ and Actinomucor taiwanensis (11) are used as pure-culture starters in the manufacture of Chinese fu-ru, or sufu. The process of preparing sufu starts with the production of soy milk by soaking dehulled soybeans, grinding, sieving, and cooking the watery extract, the latter to inactivate trypsin inhibitors and reduce some of the undesirable beany flavor. Next, a coagulation step is carried out, by adding salts (calcium or magnesium sulfate) or acid, in order to obtain a precipitate of mainly soy protein and entrapped lipids. This precipitate is collected and pressed to obtain sheets of tofu (soybean curd) of the required moisture content and firmness. After cutting of the tofu into cubes (dices), the tofu is inoculated with a suspension of mold spores. Incubation for a few days usually results in luxuriant mycelial development, giving the dices a fluffy appearance. These are now called pehtze, containing about $74 \%$ water, $12 \%$ protein, and $4.3 \%$ lipid. After flattening of the mycelium to form a protective skin on the cubes, they are submerged in a maturation mix and stored for several months to develop into a flavorsome, soft, cheeselike product. The main functions of the maturation mix are preservation, flavoring, and coloring. Preservation of sufu is achieved by a combination of salt and alcohol (rice beer may be used), whereas ang-kak and other ingredients impart specific flavor and color to the product (21). Depending upon the desired flavor and color, pehtzes may be submerged in salted, fermented rice or soybean mash, fermented soybean paste, or a solution containing 5 to $12 \%$ sodium chloride, red rice, and $10 \%$ ethanol. Red rice and soybean mash impart a red color to sufu. Use of brine containing high levels of ethanol results in sufu with a marked alcoholic bouquet. The major functions of the molds in this process are the formation of a protective layer of mycelial biomass surrounding the pehtze cubes and, most importantly, the release of several enzymes that are responsible for the partial degradation of the protein, fiber, and lipid fractions in pehtze during the maturation. This degradation results in softening of the texture, solubilization of constituents, and accumulation of flavor-enhancing compounds, such as glycine and glutamic acid $(20,36)$. In view of the optimization of industrial sufu-making processes, the response of Actinomucor elegans to temperature, salt, and alcohol has been studied. The higher the salt and alcohol levels during the maturation, the slower the enzymatic reactions take place, thus requiring longer maturation times. With the objective of accelerating the maturation, the salt and alcohol levels could be lowered. This is feasible to a level of about $10 \%$ alcohol in combination with $6 \%$ salt; at lower levels the product is susceptible to spoilage by LAB, however, as well as survival of pathogens and enterotoxin formation by Staphylococcus aureus.

\section{Tempeh}

Tempeh (the Indonesian spelling is "tempe") is made from cooked seeds (those of soybeans, cereals, or others) or seed-processing by-products by solid-state fungal fermentation $(47,48)$. Tempeh is an attractive nonmeat protein food that can be used as an ingredient in a large variety of traditonal Indonesian dishes as well as in Western-style spreads, snacks, and burgers.

Soybeans are soaked in water at ambient temperature overnight or until hulls (testae) can be easily removed by hand. LAB and yeasts predominant in water in which soybeans have been soaked are Lactobacillus casei, Lactococcus spp., Pichia burtonii, Candida diddensiae, and Rhodotorula mucilaginosa (40). Fermentative acidification during the soaking stage has been shown to suppress the growth of spoilage and pathogenic bacteria (48).

After removal of the hulls from the soaked soybeans, cotyledons are cooked for 30 to $60 \mathrm{~min}$, drained, and cooled. In the traditional tempeh process, simple methods are employed for the inoculation of the cooked beans. In principle, it is possible to use some previously made tempeh as inoculum (32); however, as tempeh contains a considerable population of bacteria other than those desired for fermentation, the reuse of tempeh as an inoculum incurs the risk of fermentation failure due to bacterial overgrowth. Therefore, professional tempeh manufacturers use traditional mold spore concentrates. These are, e.g., harvested from cooked rice on which selected strains of Rhizopus oligosporus have been cultured or cooked soybeans that have been held between leaves of Hibiscus tiliaceus (the waru tree). The latter type of widely used starter, made by specialized households, is available in the public markets in Indonesia.

The inoculated beans are then spread onto bamboo frames, wrapped in a punctured plastic sheet or between banana leaves, and allowed to ferment at ambient temperature $\left(25\right.$ to $\left.30^{\circ} \mathrm{C}\right)$ for 1 to 2 days. At this point, the 
soybeans are covered with white Rhizopus oligosporus mycelium and bound together as a cake (32). Aerobic mold growth requires oxygen and produces heat and carbon dioxide. Care should be taken that the beans do not dehydrate and that no overheating $\left(>40^{\circ} \mathrm{C}\right)$ occurs. This is achieved by allowing only restricted access of air to the beans and by limiting the thickness of the bean layers or packages (47).

Several factors may limit the acceptability and shelf life. These include the production of black sporangia and spores, indicating inadequate fermentation conditions, which results in an undesirable gray color, and enzymatic browning, comparable to the browning of cut apples, which is initiated by prolonged storage or mechanical abuse. Whereas freshly fermented tempeh has an attractive mushroom-like flavor, prolonged storage may lead to yeasty off-odors or ammoniacal odors resulting from excessive protein and amino acid degradation.

During fermentation, carbohydrases, lipases, proteases, phytases, and other enzymes degrade macromolecular substrates, resulting in very significant increases in water-soluble nutrients for enhanced digestion, biosynthesis of B vitamins such as folate (18), and transformation of soy isoflavones into health-promoting antioxidant compounds (47).

\section{Wadi and Papad}

Wadi (wari) is prepared by soaking dal (dehusked split beans), generally of black gram (Phaseolus mungo), in water for 6 to $12 \mathrm{~h}$, draining, grinding into a smooth soft dough, and fermenting for 1 to 3 days at 20 to $27^{\circ} \mathrm{C}$, with or without spices but with salt and backslop added. In an alternative method, the dough is combined with shredded waxgourd (Benincasa hispida) and whisked vigorously until it becomes light and fluffy due to the incorporation of air. The fermented or whisked dough is hand-molded into cones or balls ( 3 to $8 \mathrm{~cm}$ in diameter), deposited onto bamboo or palm mats smeared with oil, and sun dried for 4 to 8 days (6). The surface of the cones or balls becomes covered with a mucilaginous coating which retains the gas formed during fermentation within them. The wadis look hollow with many air pockets and yeast spherules in the interior and have a characteristic surface crust.

Initially the microflora includes LAB, Bacillus spp., flavobacteria, and yeasts. Gradually, a domination by gas-producing $L$. mesenteroides, $L b$. fermentum, S. cerevisiae, and Trichosporon cutaneum is achieved. Candida vartiovaarae and Kluyveromyces marxianus are also often found. Summer is more favorable for the prevalence of bacteria, and winter is more favorable for the yeasts (67). The production of acid and gas results in a decrease of $\mathrm{pH}$ from 5.6 to 3.2 , an increase in total acid (as lactic acid) from 0.5 to $1.5 \%$, and a twofold increase in the volume of the dough. The LAB are mainly responsible for acidification of dough, a condition which favors the growth of yeasts and leavening. Fermentation brings about a significant increase in soluble solids, nonprotein nitrogen, soluble nitrogen, free amino acids, and $\mathrm{B}$ vitamins. Most of these changes cause improvement in digestibility and nutritional value. Increase in total acidity during fermentation helps to enhance the shelf life of the product (66).

Papad (papadam, or appalam) is a thin, usually circular, wafer-like product used to prepare curry or eaten as a crackly snack or appetizer with meals after roasting or deep frying. In the indigenous method of preparation, black gram flour alone or blended with Bengal gram (Cicer arietinum), lentil (Lens culinaris), red gram, or green gram (Phaseolus aureus) flour is hand-kneaded with a small quantity of peanut oil, common salt (about $8 \%$ ), papad khar (a natural additive), and water and then beaten or pounded into a stiff paste. The paste may be seasoned with spices. The dough (sometimes with backslop added) is left to ferment for 1 to $6 \mathrm{~h}$ and then formed into long cylinders and cut and shaped into small balls which are rolled into thin, circular flat sheets $(10$ to $24 \mathrm{~cm}$ in diameter, 0.2 to $1.2 \mathrm{~mm}$ thick) by using a wooden rolling pin and generally dried under shade to 12 to $17 \%$ moisture content $(6,64)$. C. krusei and $S$. cerevisiae are involved in fermenting the dough, presumably resulting in modest leavening.

\section{CEREAL-LEGUME MIXTURE PRODUCTS}

\section{Idli}

Idli is a classical example of cereal-legume mixture food that provides an improved balance of carbohydrates and proteins. Because of its appealing sour flavor, spongy texture, nutritional quality, and easy digestibility, idli is also fed to infants as a complementary food and is used as a main dish in diets provided to patients in hospitals (49).

The substrates used in preparing idli are white polished rice and black gram dal (1:4 to 4:1), which are washed and soaked in water separately at ambient temperature for 5 to $10 \mathrm{~h}$. While rice is coarsely ground, the dal is ground into a smooth, mucilaginous paste. The two slurries are combined generally in the ratio of $2: 1$ and stirred well with added salt $(0.8 \%)$ to form a thick batter which is put in a closed container and left in a warm place $\left(25\right.$ to $\left.35^{\circ} \mathrm{C}\right)$ to ferment overnight or longer (14 to $24 \mathrm{~h}$ ). The fermentation period must allow a definite leavening (two- to threefold increase in volume) of 
the batter and development of a pleasant acid flavor. The fermented batter is poured into small cups ( 8 to $10 \mathrm{~cm}$ in diameter) and steamed in a covered pan to yield a soft, spongy product (39). The open texture is attributed to the protein (globulin) and polysaccharide (arabinogalactan) in black gram (71).

Although bacteria and yeasts that participate in the fermentation are generally introduced by the substrates, it is often the practice to add backslop to the newly ground substrates. With the progress of fermentation, both bacterial and yeast cell numbers increase significantly, with a concomitant decrease in $\mathrm{pH}$ and an increase in the volume of the batter and its amylase and protease activities. $L$. mesenteroides is the most commonly encountered bacterium, followed by $L b$. fermentum, Enterococcus faecalis, and Pediococcus dextrinicus (39). During fermentation, along with $L$. mesenteroides, yeasts such as $S$. cerevisiae, Debaryomyces hansenii, Pichia anomala, and Trichosporon pullulans are predominant, and Trichosporon cutaneum develops subsequently. $S$. cerevisiae is the only yeast that eventually persists (68).

The major functions of the fermentation of idli include the leavening of batter and improvement of flavor and nutritional value. The role of LAB is to reduce the $\mathrm{pH}$ of the batter from an initial 6.0 to an optimum level (4.1 to 4.5) for yeast activity. The LAB may also play a role in the breakdown of phytate present in black gram. L. mesenteroides isolated from soy idli secretes $\beta-N$-acetylglucosaminidase and $\alpha$-D-mannosidase, which are involved in the hydrolysis of hemagglutinin. Yeasts help in the degradation of starch, a process that cannot be carried out by $L$. mesenteroides, into maltose and glucose by producing extracellular amylolytic enzymes. Yeasts also produce carbon dioxide and play a significant role in leavening. Fermentation of batter by inoculating the ingredients with yeasts individually and in combination with L. mesenteroides has revealed that yeasts contribute not only to gas production, resulting in good texture, but also to sensory qualities. The higher activity of amylases and levels of B vitamins and free amino acids attained in yeast-enriched fermentations represent positive contributions of yeasts (73).

\section{Miso}

Fermented soybean pastes are known as miso in Japan, chiang in China, jang or doenjang in Korea, taoco in Indonesia, and tao chieo in Thailand. In addition to soybeans and salt, most of these products contain cereals such as rice or barley (38). Miso is fermented using Aspergillus oryzae and a yeast, Zygosaccharomyces rouxii. Sometimes, Tetragenococcus halophila and Enterococcus faecalis are also involved in the fermentation. Heat-treated rice and/ or soybeans are used to prepare shinshu or rice-soybean miso. After the initial solid-state fermentation dominated by Aspergillus oryzae, salt (38\% of the original weight of dry soybeans) is added to the koji and mixed thoroughly. The mixture is inoculated with $Z$. rouxii; traditionally, sound miso from a previous batch is used to inoculate the koji-soybean-salt mixture prior to fermentation. Although halophilic yeasts such as Torulopsis versatilis may be present, only Z. rouxii produces the desired metabolites for an acceptable product. The mixture, known as green miso, is packed into vats or tanks to undergo anaerobic fermentation and aging at 25 to $30^{\circ} \mathrm{C}$. White miso takes about 1 week, salty miso takes 1 to 3 months, and soybean miso takes over 1 year. White miso contains 4 to $8 \%$ salt, which permits rapid fermentation, and yellow or brown misos contain 11 to $13 \%$ salt. Moisture content ranges from 44 to $52 \%$, protein content ranges from 8 to $19 \%$, carbohydrate content ranges from 6 to $30 \%$, and fat content ranges from 2 to $10 \%$, depending on the ratio of soybeans, rice, and barley used as ingredients.

During fermentation and aging, soybean protein is digested by proteases produced by Aspergillus oryzae in the koji. Amino acids and their salts, particularly sodium glutamate, contribute to flavor. The addition of commercial enzyme preparations to enhance fermentation has met with some success. The relative amount of carbohydrates in miso is a reflection of the amount of rice in the product. Starch is extensively saccharified by koji amylases to yield glucose and maltose, some of which is utilized as a source of energy by the microorganisms responsible for fermentation. Miso contains 0.6 to $1.5 \%$ acids, mainly lactic, succinic, and acetic. Esters of ethyl and higher alcohols with fatty acids in soybean lipid are important in giving miso its characteristic aroma. Up to $35 \%$ of the initial lipid content is degraded into fatty acids; the extent of maturation can be conveniently monitored by the levels of fatty acid ethyl esters (75). Furanones HEMF [4-hydroxy-2(or 5)-ethyl-5(or 2)methyl-3(2H)-furanone] and HDMF [4-hydroxy-2, 5dimethyl-3 $(2 H)$-furanone] produced by $Z$. rouxii have been identified as important flavor components in miso. Miso also contains B vitamins (riboflavin and cyanocobalamin) as a result of yeast fermentation. Miso is considered to be a health-promoting, functional food, offering protection against gastrointestinal disorders; cancers of the breast, stomach, and colon; and cholesterol-associated and degenerative diseases (38).

\section{Soy Sauces}

Soy sauces are light to dark brown liquids with meat-like salty flavor used in cooking and as a table condiment. Traditionally made in the Orient, they are now also 
produced in Europe and the Americas. In Japan, there are several distinguished types, including Koikuchi, Usukuchi, Tamari, Saishikomi, and Shiro soy sauces, all having characteristic colors and flavors. All contain relatively high levels (17 to $19 \%$ ) of salt and are used to enhance the flavors of meats, seafoods, and vegetables. Typical ranges in other characteristics are as follows: $\mathrm{pH}$ 4.6 to 4.8 and 0.5 to $2.5 \mathrm{~g}$ of total nitrogen, 0.2 to $1.1 \mathrm{~g}$ of formol nitrogen, 3.8 to $2.0 \mathrm{~g}$ of reducing sugar, and traces to $2.2 \mathrm{ml}$ of ethanol (per $100 \mathrm{ml}$ ).

There are two specific fermentation stages involved in soy sauce production, the first being an aerobic koji fermentation. Seed (tane) koji is produced by culturing single or mixed strains of Aspergillus oryzae or Aspergillus sojae on either steamed, polished rice or a mixture of wheat bran and soybean flour. Seed koji is added to a soybean-wheat mixture at a concentration of 0.1 to $0.2 \%$ and fermented into what is then simply called koji. The second stage is an anaerobic moromi or salt mash which undergoes $\mathrm{LAB}$ and yeast $(Z$. rouxii) fermentations.

The two main groups of enzymes produced by Aspergillus oryzae during koji fermentation are carbohydrases $(\alpha$-amylases, amyloglucosidase, maltase, sucrase, pectinase, $\beta$-galactosidase, cellulase, hemicellulase, and pentosan-degrading enzymes) and proteinases, although lipase activity has also been reported. These enzymes hydrolyze carbohydrates to sugars and proteins to produce amino acids and low-molecular-weight peptides. These soluble products are essential for yeast and bacterial activities during the moromi fermentation $(2,12)$. In the moromi fermentation, Tetragenococcus halophila initially proliferates and produces lactic acid, which lowers the $\mathrm{pH}$ to 5.5 or less. This is followed by the growth of acidtolerant yeasts, notably $Z$. rouxii, which produce about $3 \%$ alcohol and several compounds that contribute to the characteristic aroma of soy sauce.

Although $Z$. rouxii is the dominant moromi yeast, other yeasts such as Candida versatilis and Candida etchellsii also produce phenolic compounds which contribute to soy sauce aroma. Nearly 300 flavor compounds have been identified in Japanese soy sauce (50); major categories are summarized in Table 38.3. Z. rouxii produces flavor compounds, including alcohols, glycerol, esters, and furanones. Of the latter, HEMF produced by $Z$. rouxii and Candida spp. gives Japanese-type soy sauce its characteristic flavor (22). This compound is also reported to have antitumor and antioxidative properties (33). Notwithstanding their high salt contents, soy sauces require pasteurization and adequate bottling for preservation.

\section{VEGETABLE PRODUCTS}

\section{Kimchi}

Kimchi is a generic term used to denote a group of fermented vegetable foods in Korea. More specific names are used for these products, depending on the substrate, processing method, season, and locality. Each family has its own recipe handed down from generation to generation. T'ong baegu'u-kimchi, the most common kimchi, is

Table 38.3 Major flavor components in soy sauce

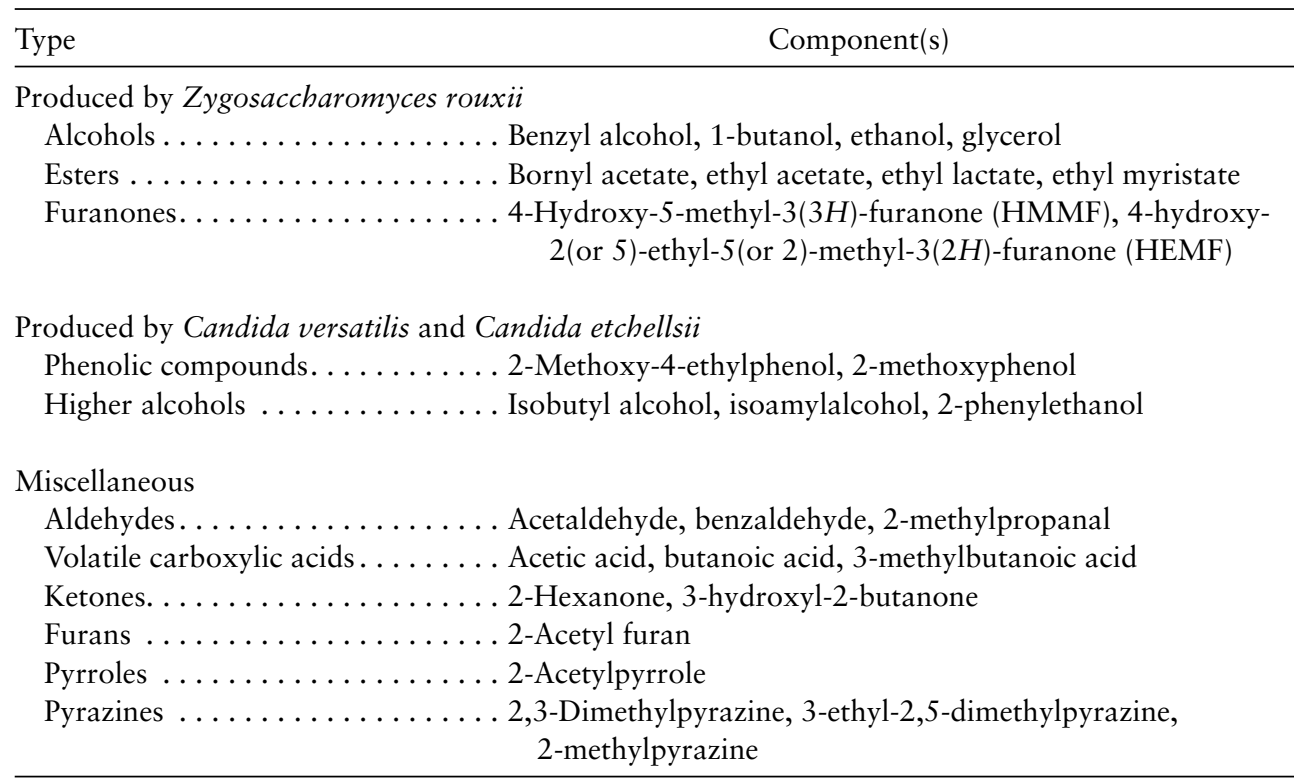


made by cutting Chinese-type cabbage into two or four parts and adding salt (approximately $3 \%$ ), followed by rinsing; draining; packing in layers with premixed garlic, onion, ginger, hot pepper powder, and salt; and fermenting for 2 to 3 days at around $20^{\circ} \mathrm{C}$. The flavor of kimchi is dependent on the ingredients, fermentation conditions, and $\mathrm{LAB}$ involved in the fermentation (34). There is a succession of microfloras during kimchi production. $L$. mesenteroides is a major bacterium found in the initial to the middle stage of fermentation. Weissella confusa and Leuconostoc citreum present in the raw materials also initiate and remain present throughout the fermentation period, indicating their importance in kimchi production. $L b$. brevis and $L b$. plantarum, which appear at the middle stage of fermentation, are overtaken by Lactobacillus sakei and Lb. curvatus, which dominate the late stage of fermentation when the $\mathrm{pH}$ decreases to 3.9 (35). They produce various constituents such as lactic acid, acetic acid, ethanol, carbon dioxide, mannitol, and dextran that impart a good flavor to kimchi. Kimchi closely resembles sauerkraut. The optimal range in salt concentration in sauerkraut is 0.7 to $3.0 \%$, and that in kimchi is 3.0 to $5.0 \%$, and secondly, kimchi is less sour than sauerkraut but carbonated.

\section{FISH PRODUCTS}

Basically salt-fermented fish products are popular in the Orient (34). Where large quantities $(>20 \%)$ of salt are added, fermentation by microorganisms is largely suppressed and enzymes from fish flesh and gut cause proteolysis of the fish. To allow fermentation to gain more importance, a source of carbohydrate is added so that LAB prevail and ferment the carbohydrate into organic acids, which reduces the high buffering capacity of the fish to result in a rapid decrease in $\mathrm{pH}$, aiding preservation and production of a tangy odor (58). To prepare low-salt fermented products like Korean sik-hae (side dish), whole fish is degutted; stripped; mixed with salt (6 to $7 \%$ ); cured overnight; drained; mixed with cooked millet ( 7 to $8 \%$ ), minced garlic ( 3 to $4 \%$ ), and red pepper powder (8 to $9 \%$ ); and packed in an earthen jar for fermentation at $20^{\circ} \mathrm{C}$ for 1 week. The jar is then kept in a cool place for 3 to 6 weeks to develop optimum flavor. The $\mathrm{pH}$ decreases rapidly during the first 3 to 5 days from 6.5 to $<5.0$, and softening begins after 3 days of fermentation. The amino- $N$ concentration increases steadily up to 14 days, and this increase coincides with the attainment of optimum flavor. The important fermenting organisms are L. mesenteroides and Lb. plantarum (34). Garlic affects the microflora by inhibiting the growth of gram-negative bacteria, in particular, due to its allicin content and by stimulating the growth of $\mathrm{LAB}$ due to the supply of fermentable fructose from its inulin reserve.

\section{MISCELLANEOUS PRODUCTS}

\section{Kombucha}

For kombucha, black tea leaves are steeped in boiling water, combined with sugar ( 5 to $15 \%$ ), cooled, inoculated, and left for 7 to 14 days, during which a film grows on the surface. When sufficiently thick (ca. $2.5 \mathrm{~cm}$ ), the film falls to the bottom and further film develops on the surface. This biofilm is used as a starter for new batches; the liquid ( $\mathrm{pH}$ of ca. 2.5) is claimed to benefit health (19). The cellulosic pellicle is a result of symbiotic associations of acetic acid bacteria, chiefly Acetobacter aceti subsp. xylinus, and various yeasts, e.g., Brettanomyces, Zygosaccharomyces, and Saccharomyces spp. Among them, Zygosaccharomyces kombuchaensis is the dominant species. Ethanol-producing yeasts are succeeded by acid-producing bacteria.

\section{Palm Wines}

The sap obtained from decapitated inflorescence of palm is fermented to produce wine. There is an art in binding the flower spathes, pounding to cause the sap to flow properly by cutting the spathe tip, and collecting the sap. The fermentation starts as soon as the sap flows into a container, and within a few hours it becomes reasonably high in alcohol content (up to $4 \%$ ). The palm wine fermentation is always an alcoholic-lactic-acetic one, involving yeasts, LAB, and acetic acid bacteria. The microorganisms responsible are mainly S. cerevisiae, Schizosaccharomyces pombe, $L b$. plantarum, and L. mesenteroides. The LAB are responsible for the consistency and soluble white coloration of palm wines through the production of glucans (29).

\section{NUTRITION AND HEALTH-PROMOTING ASPECTS}

Many traditional fermented foods are staples in the diets of vast populations of people who would otherwise have less than minimum intakes of protein and/or calories. Although the quality or quantity of proteins in vegetable-based fermented foods generally is not dramatically increased over that in raw substrates, digestibility may be improved through fermentation. Antinutritional factors in plant materials, e.g., protease inhibitors and lectins in leguminous seeds and phytic acid in cereals and seeds, may actually be reduced by fermentation. Factors that inhibit digestive activity, or that form indigestible 
complexes with proteins and minerals, are degraded during fermentation processes by endogenous (plant) and microbial enzymes. Naturally occurring toxic components, e.g., cyanogenic glycosides and glucosinolates, can be degraded substantially in fermented foods, rendering inedible materials into wholesome foods. Food components such as soybean isoflavones may be transformed into potent antioxidant aglycones, which have potential for reducing hypertension, cardiovascular ailments, and cancer, as a result of food fermentation. A significant synthesis of vitamins, especially B vitamins such as thiamine, niacin, folate, and riboflavin, contributes to the bioenrichment of foods (69).

The presence of large numbers of microorganisms (e.g., LAB) in fermented foods such as yogurt may have probiotic effects, i.e., supporting a healthy balance of the gut microbiota and offering enhanced colonization resistance and immunoresistance to the host (46). The positive contribution of traditional fermented foods to the nutritional well-being and health of those who consume them on a regular basis is widely recognized.

\section{FOOD SAFETY ASPECTS}

Of interest to food microbiologists and sanitarians is the possibility of microorganisms' producing toxic substances or of pathogenic microorganisms' surviving during fermentation or storage of indigenous fermented foods. An investigation of the aflatoxin-forming ability of aspergilli used in the Japanese food industry revealed that although fluorescent compounds were formed, none produced aflatoxin. Recently it was found that Aspergillus oryzae and Aspergillus sojae, typical "domesticated" industrial molds that have been used for centuries in the production of koji for soy sauce and miso, are incapable of forming aflatoxins. The aflR gene (aflatoxin pathwayspecific regulatory gene) is impaired in its ability to activate transcription of aflatoxin biosynthetic genes and is unable to interact with aflJ (coactivator gene) (10). The inability of potentially toxigenic molds to form mycotoxins in food fermentations may be caused by altered gene expression, unfavorable food environment, or competition with other microorganisms.

A variety of pathogenic bacteria, viruses, and parasites may occur in raw ingredients or in fermented foods due to postprocessing contamination. Whereas many gramnegative bacteria cannot survive when exposed to acidic and/or elevated salt, alcohol, or sugar conditions, many other bacteria survive such stress conditions. Viruses and parasitic cysts can be eradicated only by adequate heat treatments. Safety of fermented foods must be evaluated and controlled on the basis of safety management approaches, i.e., the hazard analysis and critical control point system (1) (see chapter 46 in this volume). Although traditional fermented foods have a history of safe use, adequate measures for hygienic processing and protection against contamination must be implemented.

\section{MODERN TOOLS IN RESEARCH AND DEVELOPMENT OF FERMENTED FOODS}

The food industry is in continuous transition, adopting an innovative and market-oriented position (13). Within this trend, there are ample opportunities for genomicsbased approaches to be applied in the fermented food industry. These include transcriptomics, proteomics, and other postgenomics approaches and are important new tools that may be applied to optimize processes and to gain a better insight into mechanisms. In view of the protection of origin (a.o.c., or certified origin of production), an unequivocal characterization of traditional fermented foods and their microflora will be required; this could be based on combinations of food compositional analysis and metabolomics (46).

In addition, these so-called "-omics" approaches offer opportunities to develop novel products and diversify processes. Innovative processes using nontraditional fermentation conditions, e.g., immobilized cells or agitated solid-state fermentors, or using pure-culture inoculation instead of multistrain natural fermentations, may invoke changes in secondary metabolite production. In view of maintaining the character of the food, as well as safeguarding safety for the consumer, the impact of novel processing should be investigated, understood, and possibly controlled. -Omics approaches will also offer opportunities to advance indigenous fermented food quality assurance and allow running cost to be reduced to more affordable levels. Finally, in the field of probiotics, -omics offer analytical approaches to substantiate health claims.

\section{References}

1. Adams, M. R., and M. J. R. Nout (ed.). 2001. Fermentation and Food Safety. Aspen Publishers, Gaithersburg, Md.

2. Aidoo, K. E., J. E. Smith, and B. J. B. Wood. 1994. Industrial aspects of soy sauce fermentations using Aspergillus, p. 155-169. In K. A. Powell, A. Renwick, and J. F. Peberdy (ed.), The Genus Aspergillus: from Taxonomy and Genetics to Industrial Application. Plenum Press, New York, N.Y.

3. Akihisa, T., H. Tokuda, K. Yasukawa, M. Ukiya, A. Kiyota, N. Sakamoto, T. Suzuki, N. Tanabe, and H. Nishino. 2005. Azaphilones, furanoisophthalides, and amino acids from the extracts of Monascus pilosus-fermented rice (redmold rice) and their chemopreventive effects. J. Agric. Food Chem. 53:562-565. 
4. Ampe, F., N. Ben-Omar, C. Moizan, C. Wacher, and J. P. Guyot. 1999. Polyphasic study of the spatial distribution of microorganisms in Mexican pozol, a fermented maize dough, demonstrates the need for cultivation-independent methods to investigate traditional fermentations. Appl. Environ. Microbiol. 65:5464-5473.

5. Batra, L. R. 1981. Fermented cereals and grain legumes of India and vicinity, p. 547-553. In M. Moo-Young and C. W. Robinson (ed.), Advances in Biotechnology, vol. 2. Fuels, Chemicals, Foods and Waste Treatment. Pergamon Press, New York, N.Y.

6. Batra, L. R., and P. D. Millner. 1974. Some Asian fermented foods and beverages and associated fungi. Mycologia 66:942-950.

7. Benjamin, C. R., and C. W. Hesseltine. 1957. The genus Actinomucor. Mycologia 49:240-249.

8. Brown, A. C., and A. Valiere. 2004. The medicinal uses of poi. Nutr. Clin. Care 7:69-74.

9. Campbell-Platt, G. 1980. African locust bean (Parkia species) and its West African fermented food product, dawadawa. Ecol. Food Nutr. 9:123-132.

10. Chang, P. K. 2004. Lack of interaction between AFLR and AFLJ contributes to nonaflatoxigenicity of Aspergillus sojae. J. Biotechnol. 107:245-253.

11. Chou, C. C., F. M. Ho, and C. S. Tsai. 1988. Effects of temperature and relative humidity on the growth of and enzyme production by Actinomucor taiwanensis during sufu pehtze preparation. Appl. Environ. Microbiol. 54:688-692.

12. Chou, C.-C., and J.-H. Rwan. 1995. Mycelial propagation and enzyme production in koji prepared with Aspergillus oryzae on various rice extrudates and steamed rice. $J$. Ferment. Bioeng. 79:509-512.

13. De Vos, W. M. 2005. Frontiers in food biotechnologyfermentations and functionality. Curr. Opin. Biotechnol. 16:187-189.

14. Dung, N. T. P. 2004. Defined fungal starter granules for purple glutinous rice wine. Ph.D. thesis. Wageningen University, Wageningen, The Netherlands.

15. Fleet, G. H. 1998. The microbiology of alcoholic beverages, p. 217-262. In B. J. B. Wood (ed.), Microbiology of Fermented Foods, 2nd ed., vol. 1. Blackie Academic \& Professional, London, United Kingdom.

16. Gänzle, M. G., and R. F. Vogel. 2002. Contribution of reutericyclin production to the stable persistence of $\mathrm{Lac}$ tobacillus reuteri in an industrial sourdough fermentation. Int. J. Food Microbiol. 80:31-45.

17. Gashe, B. A. 1985. Involvement of lactic acid bacteria in the fermentation of tef (Eragrostis tef), an Ethiopian fermented food. J. Food Sci. 50:800-801.

18. Ginting, E., and J. Arcot. 2004. High-performance liquid chromatographic determination of naturally occurring folates during tempe preparation. J. Agric. Food Chem. 52:7752-7758

19. Greenwalt, C. J., K. H. Steinkraus, and R. A. Ledford. 2000. Kombucha, the fermented tea: microbiology, composition, and claimed health effects. J. Food Prot. 63:976981.
20. Han, B. Z., F. M. Rombouts, and M. J. R. Nout. 2004 Amino acid profiles of sufu, a Chinese fermented soybean food. J. Food Comp. Anal. 17:689-698.

21. Han, B. Z., F. M. Rombouts, and M. J. R. Nout. 2001. A Chinese fermented soybean food. Int. J. Food Microbiol. 65:1-10.

22. Hanya, Y., and T. Nakadai. 2003. Yeasts and soy products, p. 413-428. In T. Boekhout and V. Robert (ed.), Yeasts in Food: Beneficial and Detrimental Aspects. B. Behr's Verlag GmbH \& Co. KG, Hamburg, Germany.

23. Hounhouigan, D. J., M. J. R. Nout, C. M. Nago, J. H. Houben, and F. M. Rombouts. 1993. Changes in the physico-chemical properties of maize during natural fermentation of mawe. J. Cereal Sci. 17:291-300.

24. Inatsu, Y., K. Kimura, and Y. Itoh. 2002. Characterization of Bacillus subtilis strains isolated from fermented soybean foods in Southeast Asia: comparison with B. subtilis (natto) starter strains. Jpn. Agric. Res. Q. 36:169-175.

25. Ishikawa, H., K. Okubo, and T. Oki. 1972. Characteristic spinnability of a natto mucin solution. Nippon Kagaku Kaishi 11:2171-2177.

26. Jakobsen, M., M. D. Cantor, and L. Jespersen. 2001 Production of bread, cheese and meat, p. 1-22. In $\mathrm{H}$. D. Osiewacz (ed.), The Mycota, Industrial Applications, vol. 10. Springer-Verlag, New York, N.Y.

27. Jenson, I. 1998. Bread and bakers' yeast, p. 172-198. In B. J. B. Wood (ed.), Microbiology of Fermented Foods, 2nd ed., vol. 1. Blackie Academic \& Professional, London, United Kingdom.

28. Jespersen, L., M. Halm, K. Kpodo, and M. Jakobsen. 1994. Significance of yeasts and moulds occurring in maize dough fermentation for "kenkey" production. Int. J. Food Microbiol. 24:239-248.

29. Joshi, V. K., D. K. Sandhu, and N. S. Thakur. 1999. Fruit based alcoholic beverages, p. 647-744. In V. K. Joshi and A. Pandey (ed.), Biotechnology: Food Fermentation, vol. 2. Educational Publishers, Ernakulam, India.

30. Kelly, W. J., R. V. Asmundson, G. L. Harrison, and C. M. Huang. 1995. Differentiation of dextran-producing Leuconostoc strains from fermented rice cake (puto) using pulsed-field gel electrophoresis. Int. J. Food Microbiol. 26:345-352.

31. Ko, S. D. 1986. Indonesian fermented foods not based on soybeans, p. 67-84. In C. W. Hesseltine and H. L. Wang (ed.), Mycologia Memoir, no. 11. Indigenous Fermented Food of Non-Western Origin. J. Cramer, Berlin, Germany.

32. Ko, S. D., and C. W. Hesseltine. 1979. Tempe and related foods, p. 115-140. In A. H. Rose (ed.), Microbial Biomass, vol. 4. Academic Press, London, United Kingdom.

33. Koga, T., K. Moro, and T. Matsudo. 1998. Antioxidative behaviors of 4-hydroxy-2,5-dimethyl-3(2H)-furanone and 4-hydroxy-2(or 5)-ethyl-5(or 2)-methyl-3(2H)-furanone against lipid peroxidation. J. Agric. Food Chem. 46:946-951.

34. Lee, C.-H. 1996. Lactic fermented foods and their benefits in Asia. Food Biotechnol. 5:187-197.

35. Lee, J.-S., G.-Y. Heo, J. W. Lee, Y.-J. Oh, J. A. Park, Y.-H. Park, Y.-R. Pyun, and J. S. Ahn. 2005. Analysis of kimchi microflora using denaturing gradient gel electrophoresis. Int. J. Food Microbiol. 102:143-150. 
36. Liu, Y.-H., and C. C. Chou. 1994. Contents of various types of proteins and water soluble peptides in sufu during ageing and the amino acid composition of taste oligopeptides. J. Chin. Agric. Chem. Soc. 32:276-283.

37. Matsuo, M. 2004. Low-salt O-miso produced from koji fermentation of oncom improves redox state and cholesterolemia in rats more than low-salt soybean-miso. J. Nutr. Sci. Vitaminol. (Tokyo) 50:362-366.

38. Minamiyama, Y., and S. Okada. 2003. Miso: production, properties, and benefits to health, p. 277-286. In E. R. Farnworth (ed.), Handbook of Fermented Functional Foods. CRC Press, Boca Raton, Fla.

39. Mukherjee, S. K., M. N. Albury, C. S. Pederson, A. G. Van Veen, and K. H. Steinkraus. 1965. Role of Leuconostoc mesenteroides in leavening the batter of idli, a fermented food of India. Appl. Microbiol. 13:227-231.

40. Mulyowidarso, R. K., G. H. Fleet, and K. A. Buckle. 1989. The microbial ecology of soybean soaking for tempe production. Int. J. Food Microbiol. 8:35-46.

41. Nagai, T., L.-S. Phan Tran, Y. Inatsu, and Y. Itoh. 2000. A new IS4 family insertion sequence, IS4Bsu 1 , responsible for genetic instability of poly-gamma-glutamic acid production in Bacillus subtilis. J. Bacteriol. 182:23872392.

42. Nago, M. C., J. D. Hounhouigan, N. Akissoe, E. Zanou, and C. Mestres. 1998. Characterization of the Beninese traditional ogi, a fermented maize slurry: physicochemical and microbiological aspects. Int. J. Food Sci. Technol. 33:307-315.

43. Nche, P. F., G. T. Odamtten, M. J. R. Nout, and F. M. Rombouts. 1996. Soaking determines the quality of aflata for kenkey production. J. Cereal Sci. 24:291-297.

44. Nikkuni, S., T. B. Karki, K. S. Vilkhu, T. Suzuki, K. Shindoh, C. Suzki, and N. Okada. 1995. Mineral and amino acid contents of kinema, a fermented soybean food prepared in Nepal. Food Sci. Technol. Int. 1:107-111.

45. Nout, M. J. R., and K. E. Aidoo. 2002. Asian fungal fermented food, p. 23-47. In H. D. Osiewacz (ed.), The Mycota: Industrial Applications, vol. 10. Springer-Verlag, New York, N.Y.

46. Nout, M. J. R., W. M. De Vos, and M. H. Zwietering (ed.). 2005. Food Fermentation. Wageningen Academic Publishers, Wageningen, The Netherlands.

47. Nout, M. J. R., and J. L. Kiers. 2005. Tempe fermentation, innovation and functionality: up-date into the 3rd millennium. J. Appl. Microbiol. 98:789-805.

48. Nout, M. J. R., and F. M. Rombouts. 1990. Recent developments in tempe research. J. Appl. Bacteriol. 69:609-633.

49. Nout, M. J. R., and P. K. Sarkar. 1999. Lactic acid food fermentation in tropical climates. Antonie Leeuwenhoek 76:395-401.

50. Nunomura, N., and M. Sasaki. 1992. Japanese soy sauce flavour with emphasis on off-flavours, p. 287-312. In G. Charalambous (ed.), Off-flavours in Foods and Beverages. Elsevier, Amsterdam, The Netherlands.

51. Nuraida, L., M. C. Wacher, and J. D. Owens. 1995. Microbiology of pozol, a Mexican fermented maize dough. World J. Microbiol. Biotechnol. 11:567-571.
52. Odunfa, S. A. 1988. Review: African fermented foods, from art to science. MIRCEN J. 4:259-273.

53. Ohta, T. 1986. Natto, p. 85-93. In N. R. Reddy, M. D. Pierson, and D. K. Salunkhe (ed.), Legume-based Fermented Foods. CRC Press, Boca Raton, Fla.

54. Onyekwere, O. O., I. A. Akinrele, and O. A. Koleoso. 1989. Industrialization of ogi fermentation, p. 329-362. In K. H. Steinkraus (ed.), Industrialization of Indigenous Fermented Foods. Marcel Dekker, New York, N.Y.

55. Onyekwere, O. O., I. A. Akinrele, O. A. Koleoso, and G. Heys. 1989. Industrialization of gari fermentation, p. 363410. In K. H. Steinkraus (ed.), Industrialization of Indigenous Fermented Foods. Marcel Dekker, New York, N.Y.

56. O'Toole, D. 1999. Characteristics and use of okara, the soybean residue from soy milk production-a review. $J$. Agric. Food Chem. 47:363-371.

57. Owens, J. D., N. Allagheny, G. Kipping, and J. M. Ames. 1997. Formation of volatile compounds during Bacillus subtilis fermentation of soya beans. J. Sci. Food Agric. 74:132-140.

58. Owens, J. D., and L. S. Mendoza. 1985. Enzymatically hydrolysed and bacterially fermented fishery products. J. Food Technol. 20:237-293.

59. Pastrana, L., P. J. Blanc, A. L. Santerre, M. O. Loret, and G. Goma. 1995. Production of red pigments by Monascus ruber in synthetic media with a strictly controlled nitrogen source. Process Biochem. 30:333-341.

60. Pepe, O., G. Blaiotta, G. Moschetti, T. Greco, and F. Villani. 2003. Rope-producing strains of Bacillus spp. from wheat bread and strategy for their control by lactic acid bacteria. Appl. Environ. Microbiol. 69:2321-2329.

61. Ruiz, J. A., J. Quilez, M. Mestres, and J. Guasch. 2003. Solid-phase microextraction method for headspace analysis of volatile compounds in bread crumb. Cereal Chem. $80: 255-259$.

62. Sarkar, P. K. 2005. Microbiology of traditional alkaline fermented foods, p. 899-915. In T. Satyanarayana and B. N. Johri (ed.), Microbial Diversity: Current Perspectives and Potential Applications. I. K. International, New Delhi, India.

63. Sarkar, P. K., B. Hasenack, and M. J. R. Nout. 2002. Diversity and functionality of Bacillus and related genera isolated from spontaneously fermented soybeans (Indian kinema) and locust beans (African soumbala). Int. J. Food Microbiol. 77:175-186.

64. Shurpalekar, S. R. 1986. Papads, p. 191-217. In N. R. Reddy, M. D. Pierson, and D. K. Salunkhe (ed.), LegumeBased Fermented Foods. CRC Press, Boca Raton, Fla.

65. Siebenhandl, S., L. N. Lestario, D. Trimmel, and E. Berghofer. 2001. Studies on tape ketan-an Indonesian fermented rice food. Int. J. Food Sci. Nutr. 52:347-357.

66. Soni, S. K., and D. K. Sandhu. 1990. Biochemical and nutritional changes associated with Indian Punjabi warri fermentation. J. Food Sci. Technol. 27:82-85.

67. Soni, S. K., and D. K. Sandhu. 1999. Fermented cereal products, p. 895-949. In V. K. Joshi and A. Pandey (ed.), Biotechnology: Food Fermentation, vol. 2. Educational Publishers, Ernakulam, India. 
68. Soni, S. K., and D. K. Sandhu. 1991. Role of yeast domination in Indian idli batter fermentation. World J. Microbiol. Biotechnol. 7:505-507.

69. Steinkraus, K. H. 1994. Nutritional significance of fermented foods. Food Res. Int. 27:259-267.

70. Sujaya, I. N., S. Amachi, K. Saito, A. Yokota, K. Asano, and F. Tomita. 2002. Specific enumeration of lactic acid bacteria in ragi tape by colony hybridization with specific oligonucleotide probes. World J. Microbiol. Biotechnol. 18:263-270.

71. Susheelamma, N. S., and M. V. L. Rao. 1979. Functional role of the arabinogalactan of black gram (Phaseolus mungo) in the texture of leavened foods (steamed puddings). J. Food Sci. 44:1309-1312, 1316.
72. Umeta, M., and R. M. Faulks. 1988. The effect of fermentation on the carbohydrates in tef (Eragrostis tef). Food Chem. 27:181-189.

73. Venkatasubbaiah, P., C. T. Dwarakanath, and V. S. Murthy. 1985. Involvement of yeast flora in idli batter fermentation. J. Food Sci. Technol. 22:88-90.

74. Westby, A., and D. R. Twiddy. 1992. Characterization of gari and fu-fu preparation procedures in Nigeria. World J. Microbiol. Biotechnol. 8:175-182.

75. Yamabe, S., K. Kaneko, H. Inoue, and T. Takita. 2004. Maturation of fermented rice-koji miso can be monitored by an increase in fatty acid ethyl ester. Biosci. Biotechnol. Biochem. 68:250-252. 
